\title{
Container Production Strategies Influence Root Ball Morphology
}

\author{
Edward F. Gilman and Maria Paz
}

\begin{abstract}
Poor anchorage and delayed establishment have been associated with root circling and ascending, descending, and kinked roots occurring in nursery containers. $\dot{\alpha}$ e main goal of this study was to find methods of producing from seed Swietenia mahagoni (L.) Jacq. with straight, non-deformed roots. In contrast to smooth-sided (SM) propagation containers (lin ers), roots grown in p ots constructed of thin paper were straight with few deflections. Root pruning 12-month-old SM liners when shifting to $3.8 \mathrm{~L}$ co ntainers dra matically reduced the imprint on the root system left by root deflections. Aggressive growth at the bottom of $3.8 \mathrm{~L}$ a nd $9.5 \mathrm{~L}$ sm ooth-sided containers appeared to inhibit growth in horizontal roots closer to the substrate surface, and resulted in a vertically oriented root system. In contrast, growing trees in $3.8 \mathrm{~L}$ a nd $9.5 \mathrm{~L}$ co ntainers with exceptionally porous walls produced a m ore horizontal-oriented root system similar to well-anchored trees in the landscape. Vertical roots were discouraged from developing due to an elevated and porous bottom, forcing roots to grow more horizontally higher in the root ball profile. Root deflections increased with retention time in all containers.

Key Words. Air Root Pruning; Deflected Roots; Descending Roots; Field-grown Trees; Horizontal Roots; Liners; Mechanical Root Pruning; Propagation; Straight Roots; Swietenia mahagoni.
\end{abstract}

Trees with some large diameter, straight roots close to the soil surface are well anchored in shallow (Coutts et al. 1990) and deep soils (Gilman and Wiese 2012). ái s co mpels de velopment of field a nd co ntainer nursery p roduction systems that mimic this $r$ oot morphology. Roots on es tablished trees often proliferate close to the surface in soil with low oxygen content typical in di sturbed urban soils (Gilman et al. 1987; Watson and Kupkowski 1991). Some roots elongate from existing short roots within the root ball, from cut roots at the top edge of the root ball, or adventitiously from the flare. Many large roots are oriented downward in the planted root ball for certain production systems and species (Hewitt and Watson 2009; G ilman a nd Or fanedes 2012). $\grave{\alpha} \quad$ e tree redirects the root system toward the surface after planting, which contributes to transplant shock as the tree generates either adventitious roots from near the trunk or new roots from root pruning cuts.

$\dot{\alpha}$ e downward growth and circling of roots that result from deflection in $\mathrm{p}$ ropagation (lin er) co ntainer encourages new roots to grow from the bottom of the liner root ball once planted into field soil or a larger container (Salonius et al. 2000). Decades ago, Harris et al. (1971) recognized that root pruning seedlings as they were shifted could reduce the imprint left by root deflections. Research on liners used in reforestation efforts also suggests that rootpruned seedlings produce a more symmetrical root system with ample surface roots (Krasowski 2003).

Roots o $\mathrm{n}$ s hade $\mathrm{t}$ rees in 1 arger co ntainers a lso deflect around and downward, often proliferating at the bottom (Marshall and Gilman 1998), likely due to availability of suitable air, nutrition, and water at the bottom. Root defects of temperate (Weicherding et al. 2007) and tropical (Gilman and Orfanedes 2012) trees growing in containers with more or less smooth sides are fairly easy to remove with mechanical root p runing (s having a ll $r$ oots a nd s ubstrate from the periphery), because many roots are at the extreme e dge of the root ball. From field observations, e valuation o $\mathrm{ft}$ hese $\mathrm{p}$ ractices i s o nly $\mathrm{n}$ ow beginning in $\mathrm{m}$ ainstream $\mathrm{h}$ orticulture o perations.

Certain co ntainer $t$ ypes $h$ ave $b$ een a ssociated with reduced root defects at the root ball periphery (A rnold a nd M cDonald 2006; G ilman et a 1 . 2010). Treating the in terior plastic container surface with copper is a time-tested, effective method 
for reducing root growth on the periphery of container r oot b alls (B urdett 1978; S truve 1993; Marshall and Gilman 1998). Or lander (1982) and Ortega et al. (2006) found that exposing the open container b ottom to a ir (a ir pruning) resulted in fewer deflected roots in the propagation container. $\dot{\alpha}$ e n umber a nd total len gth of Acer rubrum L . roots from stem cuttings deflected up, around, and down b y co ntainer wa lls w ere a pproximately a $n$ order of magnitude g reater in $f$ our types of plastic containers compared to those made from thin paper (Gilman et al. 2012). ải s was presumably due to a combination of root tip dieback on roots growing through the paper and in to the a ir outside the container (i.e., a ir p runing), a nd g rowth of $s$ ome of t hese $r$ oots in to ad jacent co ntainers.

$\dot{\alpha}$ e o bjective of this study wa s to find a n ursery $p$ roduction sys tem $t$ hat $p$ roduced $a r$ oot $b$ all with a ttributes simi lar t o t hose of $\mathrm{w}$ ell-anchored landscape trees; i.e., with straight roots, some close to $t$ he $s$ urface. $\mathrm{M}$ ahogany [S wietenia ma hagoni (L.) J acq.] wa s c hosen d ue t o: 1) i ts p opularity a $\mathrm{s}$ a $\mathrm{n}$ urb an $\mathrm{l}$ andscape $\mathrm{t}$ ree in $\mathrm{t}$ ropical a nd subtropical $r$ egions of Flo rida, U .S., a nd in $t$ he Caribbean, and 2) a general lack of nursery production $r$ esearch o $n t$ ropical s hade $t$ ree $r$ oot sys tems.

\section{MATERIALS AND METHODS}

On F ebruary 11, 2009, in L oxahatchee, Flo rida (USDA $h$ ardiness zo ne 10a), $m$ ahogany s eeds were $\mathrm{p}$ laced in to $\mathrm{p}$ ropagation (lin er) co ntainers in substrate consisting of $45 \%$ s uper fine pine bark, 20\% Florida peat, 10\% horticultural p erlite, $15 \%$ A llgro co mpost, and 10\% co arse s and. ảr ee $\mathrm{p}$ ropagation co ntainer $\mathrm{t}$ ypes $\mathrm{t}$ ested $\mathrm{w}$ ere: 1) B ottomless Ellepot (EP) co nstructed of paper $50 \mathrm{~mm}$ di ameter $\times 90 \mathrm{~mm} \mathrm{t}$ all, with a volume of $137 \mathrm{~cm}^{3}$ (Ellegaard, Esbjerg, Denmark, Ellepot paper m ade by A hlstrom $S$ talldalen AB, S talldalen Sweden from spruce, pine, and polyester long fibers, $27 \mathrm{~g} / \mathrm{m}^{2}, 190$ micr ons thick, $1320 \mathrm{~N} / \mathrm{m} \mathrm{dr}$ y tensile strength in $\mathrm{m}$ achine direction, $2.0 \mathrm{~N} \mathrm{t}$ ear strength), arranged $10 \mathrm{~mm}$ a part in a p lastic tray $(27 \mathrm{~cm} \times 53 \mathrm{~cm})$, w hich exposed $100 \%$ of the paper sides to air and rested on a plastic ring $(8 \mathrm{~mm}$ wide) as part of the holder tray; 2) EP w ith same dimensions placed in a tray of smooth (EPS) black plastic cells $(60 \mathrm{~mm}$ tall $\times 50 \mathrm{~mm}$ wide), spaced about $5 \mathrm{~mm}$ a part; and 3 ) a t ray of smooth-sided
(SM) black plastic containers $40 \mathrm{~mm}$ top diameter $\times 90 \mathrm{~mm}$ tall (volume $105 \mathrm{~cm}^{3}$ ) with a slightly tapered cone and a single drainage hole at the bottom. Trays (e ach with 40 t o 55 co ntainers) were arranged in a ra ndomized fa shion on wire mesh benches $80 \mathrm{~cm} \mathrm{f}$ rom the ground in $\mathrm{f}$ ull sun in a non-climate co ntrolled, o pen-sided g reenhouse.

\section{Retained in Propagation Container (5 months)}

On July 27, 2009 (5 months retention time in propagation co ntainer), t rees w ere ei ther 1) wa shed of substrate for root evaluation, 2) s hifted in to $3.8 \mathrm{~L}$ containers, or 3 ) $r$ etained in $t$ he propagation containers. On $10 \mathrm{ra}$ ndomly c hosen, wa shed $\mathrm{t}$ rees, roots $>1 \mathrm{~mm}$ di ameter were evaluated for number of roots in the top half of root ball that branched, estimated \% o f total root ball root length that was in the top half of the root ball, tap root deflected by liner bottom or not, tap root length after deflection, number of p rimary lateral roots deflected by the co ntainer $b$ ottom, $n$ umber of $p$ rimary $l$ ateral roots deflected do wnward by the co ntainer sides, and a $\mathrm{v}$ isual es timate of where ac tive root $\mathrm{g}$ rowth was occurring: either mostly in the top half of root ball, mostly in the bottom half of root ball, or evenly distributed in the root ball. Tree height and trunk diameter a $\mathrm{t} s$ ubstrate le vel $\mathrm{w}$ ere a lso $\mathrm{r}$ ecorded.

One-hundred lin ers of $\mathrm{e}$ ach $\mathrm{p}$ ropagation co $\mathrm{n}$ tainer type were shifted in to ei ther $3.8 \mathrm{~L}, 1$ ) b lack plastic sm ooth-sided s lightly-tapered co ntainers (SC1; $15.5 \mathrm{~cm}$ top diameter $\times 15.5 \mathrm{~cm}$ t all; Nursery Supplies, Inc., Chambersburg, P ennsylvania, U.S.) or 2) into containers with exceptionally porous walls and bottom (Pioneer pot; $\mathrm{PC1} ; 19 \mathrm{~cm}$ top diameter $\times 17 \mathrm{~cm} \mathrm{t}$ all, a ll co ntainer s urfaces co mposed of about $15 \%$ plastic and $85 \%$, a ir including a b ottom elevated $8 \mathrm{~cm} \mathrm{f}$ rom ground, Pioneer Farms, Visalia, California, U.S.) and placed several $\mathrm{cm}$ apart on woven ground cloth, on the ground, pot-to-pot in a randomized fa shion. Side of PC1s w ere lined with paper (as described in EP) to ensure substrate would not leach through the large (10 $\mathrm{mm}$ square) openings in the side. $\dot{\alpha}$ e resulting experimental design was a complete factorial with three propagation container types $\times$ two $3.8 \mathrm{~L}$ container types, totaling 600 trees. Substrate volume was equivalent in both $3.8 \mathrm{~L}$ containers; it reached the top in the PC1 containers and was $1 \mathrm{~cm}$ b elow the top in the SM1 containers. $\dot{\alpha} \mathrm{e}$ 
EP paper was not removed when shifting into $3.8 \mathrm{~L}$ containers. Controlled release fertilizer $\left(18 \mathrm{~N}-6 \mathrm{P}_{2} \mathrm{O}_{5}\right.$ $-1_{2} \mathrm{~K}_{2} \mathrm{O}$, Nurserymen's Sure Gro, Vero Beach, Florida, U.S.) was surface applied to substrate (60\% pine bark: $30 \%$ Florida peat: $10 \%$ sand) following shifting to the 3.8 $\mathrm{L}$ container, and no other fertilizer was applied. Trees in $3.8 \mathrm{~L}$ containers were overhead irrigated typically $\mathrm{t}$ wo o $\mathrm{t}$ hree $\mathrm{t}$ imes $\mathrm{d}$ aily in $\mathrm{t}$ he $\mathrm{g}$ rowing season, less in the dormant season. Roots remained inside co ntainers $w$ ithout rooting in to the ground and without rooting into adjacent containers. Shoots were pruned once to m aintain a do minant le ader.

In $J$ anuary $2010(6 \mathrm{~m}$ onths $r$ etention $t$ ime in 3.8 L co ntainers), $t$ rees w ere ei ther 1) wa shed, 2) retained in $3.8 \mathrm{~L}$ co ntainers, or 3 ) s hifted to $9.5 \mathrm{~L}$ containers. Ten trees in b oth $3.8 \mathrm{~L}$ co ntainer types from $t$ hree $p$ ropagation co ntainer $t$ ypes $(60 t$ rees total) were washed of substrate to measure root and shoot attributes. Root ( $>1 \mathrm{~mm}$ di ameter) attributes measured in $3.8 \mathrm{~L}$ co ntainers included \% trunk circumference circled with roots; root cull, acco rding to Florida Grades and Standards for Nursery Stock (Anonymous 1998); $\mathrm{n}$ umber of roots deflected by propagation container; visual rating of the imprint formed by the deflected roots at the position of the liner; $r$ oot dep th a nd di ameter of the 101 argestdiameter $r$ oots $m$ easured $j$ ust $b$ eyond $t$ he e dge of the propagation container position; number of the largest $10 \mathrm{r}$ oots that $\mathrm{g}$ rew o utward at les $\mathrm{s}$ than 45 degrees to substrate surface without deflecting laterally $\mathrm{m}$ ore $\mathrm{t}$ han $60 \mathrm{deg}$ rees a nd $\mathrm{r}$ eached $\mathrm{t}$ he 3.8 L co ntainer edge (s traight $r$ oots); r oot depth a nd diameter at the periphery of the $3.8 \mathrm{~L}$ co ntainer; and diameter of the five largest horizontal (0 to 45 degrees from substrate surface) and vertical (45 to 90 degrees) roots measured just beyond the edge of the propagation container. Half of the remaining trees were retained in the $3.8 \mathrm{~L}$ container until September 2010 (13 months retention time in $3.8 \mathrm{~L}$ containers), when either the same measurements were made on eight randomly chosen trees of each treatment combination, or trees were shifted into $9.5 \mathrm{~L}$ containers of the same type (SC3, model PF1200, $27 \mathrm{~cm}$ top diameter $\times 24 \mathrm{~cm}$ deep; PC3, $28 \mathrm{~cm}$ top diameter $\times 17 \mathrm{~cm}$ deep). Substrate volume was equivalent in both containers; it reached the top in the PC 3 containers and was $1 \mathrm{~cm}$ b elow the top in the SM3 containers. $\dot{\alpha} \mathrm{e}$ other half of the remaining $3.8 \mathrm{~L} t$ rees was shifted January 2010 into $9.5 \mathrm{~L}$ containers of the same type
(PC3 and SC3). Paper was not used to line the PC3 because it did $n$ ot a ppear to b e n eeded to r etain substrate. All trees remained in $9.5 \mathrm{~L}$ containers for six months regardless of when they were shifted, at which time they were washed of substrate to measure roots as des cribed for $3.8 \mathrm{~L}$ co ntainers. Trees grown under the EPS treatment were not shifted into $9.5 \mathrm{~L}$ containers due to lack of available plants.

\section{Retained in Propagation Container (12 months)}

In February 2010, $40 \mathrm{t}$ rees retained in EP a nd 40 retained in $\mathrm{S} \mathrm{M} \mathrm{p}$ ropagation co ntainers $\mathrm{f}$ or 12 months were r oot p runed; $20 \mathrm{o} f \mathrm{e}$ ach $\mathrm{w}$ ent in to $\mathrm{SC} 1$ and 20 in to PC1 $3.8 \mathrm{~L}$ co ntainers for a total of $80 \mathrm{t}$ rees ( $\mathrm{t}$ wo propagation types pruned $\times \mathrm{t}$ wo $3.8 \mathrm{~L}$ types $\times 20$ reps). $\dot{\alpha}$ e outer $5 \mathrm{~mm}$ of the root ball sides a nd b ottom wa $s \mathrm{r}$ emoved $\mathrm{w}$ ith $\mathrm{s}$ harp scissors (Fi skars, FS K01004342) b y o ne p erson to standardize procedure. $\dot{\alpha}$ e remaining 80 trees were $n$ ot root p runed $w$ hen shifted in to the SC1 (40 trees) and PC1 (40 trees) containers. à e completely ra ndomized exp erimental desig $\mathrm{n}$ wa $\mathrm{s}$ a complete factorial with $t$ wo propagation types $x$ two 3.8 L types $\times$ two root pruning treatments $\times 20$ reps $=160$ trees. Substrate in the propagation container was positioned a few $\mathrm{mm}$ below the surface of the $3.8 \mathrm{~L}$ container substrate to account for some substrate settling around the liner root $b$ all. Trees were placed in a ra ndomized manner in $\mathrm{f}$ ull $\mathrm{s}$ un and o verhead ir rigated on $\mathrm{n}$ ursery g round cloth. In A ugust 2010 (6 m onths r etention time in 3.8 $\mathrm{L}$ containers) and March 2011 (12 m onths retention time in $3.8 \mathrm{~L}$ co ntainers), t rees were shifted into $9.5 \mathrm{~L}$ co ntainers of the same type. Trees remained in $9.5 \mathrm{~L}$ co ntainers for six months regardless of when they were shifted, at which time root systems were wa shed of substrate. Measurements included those described for $3.8 \mathrm{~L}$ containers.

\section{Statistical Analysis}

All designs were completely randomized complete fac torials. A ttributes in $\mathrm{t}$ hree $\mathrm{p}$ ropagation containers h arvested in J uly $2009 \mathrm{w}$ ere a nalyzed with one-way analysis of variance (ANOVA) using the GLM p rocedure of SA S (v ersion 9.2, SA S Institute, $\mathrm{C}$ ary, $\mathrm{N}$ orth $\mathrm{C}$ arolina, U.S.) (T able 1). Attributes in two $3.8 \mathrm{~L}$ container types shifted from three $\mathrm{p}$ ropagation lin er $\mathrm{t}$ ypes $\mathrm{h}$ arvested J anuary 
2010 were analyzed with two-way ANOVA (Table 2). Attributes in two $3.8 \mathrm{~L}$ co ntainer types, grown from three propagation liner types, and retained 5 or 12 months in propagation, liners were analyzed with three-way AN OVA (Table 3). A ttributes in two $3.8 \mathrm{~L}$ container types, grown from three propagation liner types, and root pruned or not, were analyzed with three-way ANOVA (Table 4). Attributes in two $3.8 \mathrm{~L}$ containers types retained in two propagation liner types 5 months, and harvested 6 and 13 months later, were analyzed with three-way ANOVA (Table 5). Attributes in two $3.8 \mathrm{~L}$ and 9.5 L co ntainer types, grown from three propagation liner types, in each of these three treatment combinations: 1) 5 months or 2) $12 \mathrm{~m}$ onths retention in propagation container without root pruning when shifting to $3.8 \mathrm{~L}$ co ntainer, or 3) $12 \mathrm{~m}$ onths retention with root pruning, were analyzed with threeway AN OVA (Tables 6 a nd 7). A ttributes in t wo $3.8 \mathrm{~L}$ a nd $9.5 \mathrm{~L}$ co ntainer types, grown from two propagation liner types for 5 months, and retained in $3.8 \mathrm{~L}$ co ntainers for 6 or $13 \mathrm{~m}$ onths, were analyzed with three-way AN OVA (Table 8). P ercentages w ere A rcsine t ransformed p rior to a nalysis. Duncan's multiple range test was used to separate main effect m eans; in teraction m eans were co $\mathrm{m}$ pared $w$ ith LS $m$ eans a t $P<0.05$. $M$ ain effects are $\mathrm{p}$ resented and were a veraged across in significant factors when in teractions w ere in significant.

\section{RESULTS}

ảr ee-way interactions were m ostly insignificant, so they a re not des cribed in this a nalysis. Mahogany $\mathrm{p}$ ropagated in $\mathrm{S} M \mathrm{~h}$ ad $\mathrm{s}$ lightly sm aller $\mathrm{t}$ runk diameter and were shorter than trees in EP $\mathrm{w}$ hen harvested $\mathrm{f}$ rom $\mathrm{t}$ he $\mathrm{p}$ ropagation co ntainer ( $\mathrm{T}$ able 1). T rees in EP $h$ ad g reater $r$ oot $b$ ranching a nd root length in the top half of liner root balls, fewer deflected $t$ ap r oots a nd 1 ateral r oots, a nd ac tively growing $r$ oots $m$ ore e venly di stributed $\mathrm{v}$ ertically when compared to SM and EPS (Table 1; Figure 1).

Mahogany harvested from b oth $3.8 \mathrm{~L}$ co ntainer types $t$ hat $w$ ere $p$ ropagated in EPS $h$ ad a $m$ uch larger $\mathrm{p}$ ercentage of the trunk cir cled at the lin er position $(78 \%), \mathrm{p}$ roduced more trees graded a $\mathrm{s}$ root culls (79\%), a nd the imprint on the root sys tem im posed $\mathrm{b} y \mathrm{t}$ he $\mathrm{p}$ ropagation co ntainer wa $\mathrm{s}$ highly $\mathrm{v}$ isible (ra ting $=4.6) \mathrm{w}$ hen co mpared t o seedlings $g$ rown in S M a nd EP ( $\mathrm{T}$ able 2 ). $\mathrm{T}$ rees propagated in EP had the least deflected (lower \% trunk circled, \% culls, imprint rating) root systems, and those from SM had shallower roots than EPS.

Mean root depth was greater in both $3.8 \mathrm{~L}$ co ntainer $t$ ypes m easured just b eyond the position of the liner root ball when trees were retained in propagation co ntainers $12 \mathrm{~m}$ onths $(87 \mathrm{~mm})$ co mpared to 5 months ( $50 \mathrm{~mm}$, data not shown). Response to $\mathrm{r}$ etention $\mathrm{t}$ ime dep ended $\mathrm{o} \mathrm{n} \mathrm{t}$ he $\mathrm{p}$ ropagation container $t$ ype $f$ or $f$ our $m$ easured $r$ oot a ttributes

Table 1. Trunk diameter, tree height, and root (>1 mm diameter) attributes of mahogany [Swietenia mahagoni (L.) Jacq.] harvested from three propagation container types 5 months (July 2009) after seed germination.

\begin{tabular}{|c|c|c|c|c|c|c|c|c|c|}
\hline $\begin{array}{l}\text { Propagation } \\
\text { container } \\
\text { (liner) type }\end{array}$ & $\begin{array}{l}\text { Trunk } \\
\text { diameter } \\
(\mathrm{mm})\end{array}$ & $\begin{array}{l}\text { Tree height } \\
(\mathrm{cm})\end{array}$ & $\begin{array}{l}\text { No. of roots } \\
\text { in top half of } \\
\text { root ball that } \\
\text { branched }(\mathrm{cm})\end{array}$ & $\begin{array}{l}\% \text { total root } \\
\text { length in top } \\
\text { half of root } \\
\text { ball }\end{array}$ & $\begin{array}{l}\% \text { trees with } \\
\text { tap root } \\
\text { deflected at } \\
\text { bottom }\end{array}$ & $\begin{array}{l}\text { Tap root length } \\
\text { after deflection } \\
(\mathrm{mm})\end{array}$ & $\begin{array}{l}\text { No. of lateral } \\
\text { roots deflected } \\
\text { down }\end{array}$ & $\begin{array}{l}\text { No. of lateral } \\
\text { roots deflected } \\
\text { around bottom }\end{array}$ & $\begin{array}{l}\% \text { trees with active } \\
\text { root growth evenly } \\
\text { distributed vertically } \\
\text { in root ball }\end{array}$ \\
\hline SM & $3.1 \mathrm{~b}^{\mathrm{z}}$ & $18 \mathrm{~b}$ & $0.4 \mathrm{~b}$ & $23 \mathrm{~b}$ & $100 \mathrm{a}$ & $55 \mathrm{~b}$ & $4.4 \mathrm{a}$ & $6.6 \mathrm{a}$ & $0 \mathrm{a}$ \\
\hline EP & $3.8 \mathrm{a}$ & $22 \mathrm{a}$ & $3.2 \mathrm{a}$ & $55 \mathrm{a}$ & $10 \mathrm{~b}$ & $2 c$ & $0.4 \mathrm{~b}$ & $0 \mathrm{~b}$ & $40 \mathrm{~b}$ \\
\hline EPS & $3.4 \mathrm{ab}$ & $16 \mathrm{~b}$ & $0.4 \mathrm{~b}$ & $18 \mathrm{~b}$ & $100 \mathrm{a}$ & $174 \mathrm{a}$ & $0.2 \mathrm{~b}$ & $8.9 \mathrm{a}$ & $0 \mathrm{a}$ \\
\hline
\end{tabular}

${ }^{\mathrm{z}}$ Means in a column with a different letter are statistically different at $P<0.05 ; \mathrm{n}=10$.

Table 2. Effect of propagation container type on roots (>1 mm diameter) of mahogany harvested six months (January 2010) after shifting into $3.8 \mathrm{~L}$ containers ${ }^{2}$.

\begin{tabular}{lllll}
\hline $\begin{array}{l}\text { Propagation container } \\
\text { (liner) type }\end{array}$ & $\begin{array}{l}\text { \% trunk circled } \\
\text { at liner wall position }\end{array}$ & $\begin{array}{l}\text { \% trees graded as cully } \\
\text { at liner wall position }\end{array}$ & $\begin{array}{l}\text { Root system visual imprint } \\
\text { from liner wall (1-5) }\end{array}$ & $\begin{array}{l}\text { Root depth just beyond } \\
\text { position of the liner wall (mm) }\end{array}$ \\
\hline SM & $29 \mathrm{~b}^{\mathrm{w}}$ & $20 \mathrm{~b}$ & $2.6 \mathrm{~b}$ & $47.3 \mathrm{~b}$ \\
EP & $2 \mathrm{c}$ & $0 \mathrm{~b}$ & $1.4 \mathrm{c}$ & $52.1 \mathrm{ab}$ \\
EPS & $78 \mathrm{a}$ & $79 \mathrm{a}$ & $4.6 \mathrm{a}$ & $55.7 \mathrm{a}$ \\
\hline
\end{tabular}

${ }^{z}$ Values for the same attributes were similar for trees in $9.5 \mathrm{~L}$ containers (data not shown).

y Root cull according to Florida Grades and Standards for Nursery Plants (Anonymous 1998).

“ $1=$ no visible deflection or retained "cage" formed by deflected roots at the position of the propagation liner; $5=$ highly visible "cage" formed by deflected roots at the liner.

${ }^{w}$ Means in a column with a different letter are statistically different at $P<0.05 ; \mathrm{n}=20$ averaged across $3.8 \mathrm{~L}$ container type due to insignificant interaction.

Note: Roots measured just beyond the propagation container position; trees not root pruned when shifting to $3.8 \mathrm{~L}$ containers. 
Table 3. Interaction of propagation container type with retention time on mahogany roots ( $>1 \mathrm{~mm}$ diameter) harvested 6 months later from $3.8 \mathrm{~L}$ containers.

\begin{tabular}{lllll}
\hline $\begin{array}{l}\text { Propagation container } \\
\text { (liner) type }\end{array}$ & $\begin{array}{l}\text { Retention time in } \\
\text { propagation container } \\
\text { (months) }\end{array}$ & $\begin{array}{l}\text { \% trunk circled at } \\
\text { liner wall position }\end{array}$ & $\begin{array}{l}\text { \% trees graded as } \\
\text { root cull }{ }^{\mathrm{z}} \text { at liner } \\
\text { wall position }\end{array}$ & $\begin{array}{l}\text { No. of roots deflected } \\
\text { at liner wall position }\end{array}$ \\
\hline SM & 5 & $29 \mathrm{~b}^{\mathrm{x}}$ & $20 \mathrm{~b}$ & $\begin{array}{l}\text { No. of straight } \\
\text { roots } \\
\text { flare }\end{array}$ \\
$\mathrm{EP}$ & 12 & $66 \mathrm{a}$ & $86 \mathrm{a}$ & $2.7 \mathrm{ab}$ \\
& 5 & $2 \mathrm{c}$ & $0 \mathrm{~b}$ & $3.6 \mathrm{a}$ \\
$2.0 \mathrm{~b}$ & $0.7 \mathrm{c}$ \\
\hline
\end{tabular}

${ }^{2}$ Root cull according to Florida Grades and Standards for Nursery Plants (Anonymous 1998).

y Straight roots were those $>1 \mathrm{~mm}$ diameter measured just inside the $3.8 \mathrm{~L}$ container sides that grew from trunk at $<45$ degree angle to substrate surface without making a turn of $>60$ degrees relative to parent root azimuth at trunk.

${ }^{x}$ Means in a column with a different letter are statistically different at $P<0.05 ; \mathrm{n}=16$ averaged across $3.8 \mathrm{~L}$ container type due to insignificant interaction.

Note: Trees not root pruned when shifting to $3.8 \mathrm{~L}$ containers.

Table 4. Interaction of propagation container type with root pruning on mahogany roots ( $>1 \mathrm{~mm}$ diameter) harvested from 3.8 L containers 13 months after shifting (March 2011).

\begin{tabular}{llll}
\hline $\begin{array}{l}\text { Propagation container } \\
\text { (liner) type }\end{array}$ & $\begin{array}{l}\text { Roots pruned when liner was } \\
\text { shifted into 3.8 L container }\end{array}$ & $\begin{array}{l}\% \text { trees graded as root cullz } \\
\text { at liner wall position }\end{array}$ & $\begin{array}{l}\% \text { trunk circled at the } \\
\text { liner wall position }\end{array}$ \\
\hline SM & Yes & $21 \mathrm{~b}$ & $66 \mathrm{~b}$ \\
& No & $86 \mathrm{a}$ & $5 \mathrm{~b}$ \\
EP & Yes & $0 \mathrm{~b}^{\mathrm{y}}$ & $12 \mathrm{~b}$ \\
& No & $0 \mathrm{~b}$ & \\
\hline
\end{tabular}

${ }^{\mathrm{z}}$ Root cull according to Florida Grades and Standards for Nursery Plants (Anonymous 1998)

${ }^{y}$ Means in a column with a different letter are statistically different at $P<0.05 ; \mathrm{n}=14$ averaged across $3.8 \mathrm{~L}$ container types due to insignificant interaction. Results were similar for trees harvested in $9.5 \mathrm{~L}$ containers.

Note: Trees retained in propagation containers 12 months (February 2009 to February 2010) prior to root pruning when shifting.

Table 5. Interaction of $3.8 \mathrm{~L}$ container type with retention time on mahogany roots (>1 mm diameter) harvested from $3.8 \mathrm{~L}$ containers.

\begin{tabular}{|c|c|c|c|c|c|c|c|}
\hline $\begin{array}{l}3.8 \mathrm{~L} \text { container } \\
\text { type }\end{array}$ & $\begin{array}{l}\text { Retention time } \\
\text { in } 3.8 \mathrm{~L} \\
\text { container } \\
\text { (months) }\end{array}$ & $\begin{array}{l}\% \text { of total root CSA } \\
\text { in top } 2 \mathrm{~cm} \text { at } 3.8 \mathrm{~L} \\
\text { root ball periphery }\end{array}$ & $\begin{array}{l}\text { CSA five largest } \\
\text { horizontal roots } \\
\text { at } 3.8 \mathrm{~L} \text { root ball } \\
\text { periphery }^{\mathrm{z}}\left(\mathrm{mm}^{2}\right)\end{array}$ & $\begin{array}{l}\text { No. of } \\
\text { horizontal } \\
\text { roots }^{z}\end{array}$ & $\begin{array}{l}\text { Ratio diameter five } \\
\text { largest horizontal: } \\
\text { five largest } \\
\text { descending roots } \\
\text { just beyond liner } \\
\text { position }\end{array}$ & $\begin{array}{l}\text { Maximum arc } \\
\text { lacking roots } \\
\text { (degrees) }\end{array}$ & $\begin{array}{l}\text { Root depth just } \\
\text { beyond position } \\
\text { of the liner } \\
\text { periphery (mm) }\end{array}$ \\
\hline \multirow[t]{2}{*}{$\overline{\mathrm{PC} 1}$} & 6 & $17 a^{w}$ & $25 \mathrm{bc}$ & $7.8 \mathrm{a}$ & $5.7 \mathrm{a}$ & $117 \mathrm{~b}$ & $46 c$ \\
\hline & 13 & $13 \mathrm{~b}$ & $97 \mathrm{a}$ & $6.8 \mathrm{a}$ & $2.9 \mathrm{~b}$ & $90 \mathrm{~b}$ & $67 \mathrm{~b}$ \\
\hline \multirow[t]{2}{*}{ SC1 } & 6 & $6 \mathrm{~d}$ & $8 \mathrm{c}$ & $2.9 \mathrm{c}$ & $0.7 \mathrm{c}$ & $258 \mathrm{a}$ & $53 c$ \\
\hline & 13 & $8 \mathrm{c}$ & $35 \mathrm{~b}$ & $4.2 \mathrm{~b}$ & $1.0 \mathrm{bc}$ & $104 \mathrm{~b}$ & $95 \mathrm{a}$ \\
\hline
\end{tabular}

${ }^{2}$ Horizontal roots were those growing from the trunk at less than a 45 degree angle to substrate surface.

y Descending roots were those growing at an angle of between 45 and 90 degrees to substrate surface.

$x \dot{\alpha}$ e largest arc (in degrees) looking down at the top of the root ball lacking roots $>1 \mathrm{~mm}$ diameter.

${ }^{\text {w }}$ Means in a column with a different letter are statistically different at $P<0.05 ; \mathrm{n}=16$ averaged across propagation container type due to insignificant interaction.

Note: Trees retained in propagation containers 5 months (February 2009 to July 2009) and not root pruned when shifted. Finished trees in $9.5 \mathrm{~L}$ containers had similar values for most attributes (data not shown).

Table 6. Effect of container type on mahogany trunk diameter, tree height, and roots ( $>3 \mathrm{~mm}$ diameter) harvested in 9.5 L containers in April and October 2011.

\begin{tabular}{|c|c|c|c|c|c|}
\hline $\begin{array}{l}3.8 \mathrm{~L} \text { and } 9.5 \mathrm{~L} \\
\text { container type }\end{array}$ & Trunk diam. (mm) & Tree height (m) & $\begin{array}{l}\% \text { trunk circled in top half } \\
\text { of } 3.8 \mathrm{~L} \text { container }\end{array}$ & $\begin{array}{l}\% \text { trunk circled in bottom } \\
\text { half of } 3.8 \mathrm{~L} \text { container }\end{array}$ & $\begin{array}{l}3.8 \mathrm{~L} \text { visual imprint }{ }^{z} \\
\text { rating }(1-5)\end{array}$ \\
\hline PC3 & $14 \mathrm{~b}^{\mathrm{t}}$ & $1.0 \mathrm{~b}$ & $13 \mathrm{~b}$ & $2 b$ & $1.5 \mathrm{~b}$ \\
\hline SC3 & $16 \mathrm{a}$ & $1.2 \mathrm{a}$ & $24 \mathrm{a}$ & $48 \mathrm{a}$ & $4.5 \mathrm{a}$ \\
\hline
\end{tabular}

${ }^{\mathrm{z}} 1$ = no visible deflection or retained "cage" formed by deflected roots at the position of the propagation liner; $5=$ highly visible "cage" formed by deflected roots at the liner. ${ }^{y}$ Root cull according to Florida Grades and Standards for Nursery Plants (Anonymous 1998).

${ }^{x}$ Straight roots were those measured at the edge of root ball that grew from trunk at $<45$ degree angle to substrate surface without making a turn of $>60$ degrees relative to parent root azimuth at trunk.

${ }^{\text {w }}$ Horizontal roots were those growing from the trunk at less than a 45 degree angle to substrate surface; descending roots are those growing at an angle of between 45 and 90 degrees.

${ }^{v} \dot{\alpha}$ ese grew from the top of the main structural roots or trunk base and were distinguished from existing roots by their straight orientation and light coloration, typically with a long, white root tip.

" Measured just beyond the edge of the propagation container.

${ }^{\mathrm{t}}$ Means in a column with a different letter are statistically different at $P<0.05 ; \mathrm{n}=42$ averaged across propagation container type, and across these three treatment combinations due to insignificant interaction: 5 or 12 months in propagation container without root pruning when shifting to $3.8 \mathrm{~L}$ container, and 12 months retention with root pruning. 
(Table 3). In contrast to SM propagation containers, increasing retention time in EP co ntainers had no impact on \% trunk circled, \% r oot culls, and number of straight roots in $3.8 \mathrm{~L}$ containers. When held five $m$ onths, $p$ ropagation co ntainer $t$ ype $h$ ad $n o$ impact on number of roots deflected at the position of the co ntainer; h owever, w hen h eld $12 \mathrm{~m}$ onths, fewer roots deflected in EP than in SM containers.

Root pruning $\mathrm{S} M$ liners b y shaving (pruning) $5 \mathrm{~mm} \mathrm{f}$ rom the periphery r educed by a fac tor of 4 o r $5 \mathrm{t}$ he $\% \mathrm{t}$ rees in $\mathrm{b}$ oth $3.8 \mathrm{~L}$ co ntainers graded as culls and \% trunk circled, respectively (Table 4). Root pruning EP liners had no impact on 3.8 L t rees (Table 4) b ecause there were few roots deflected by the EP periphery (Table 1). Root pruning SM also in creased the \% of t otal root $(>3 \mathrm{~mm}$ diameter) $n$ umber (56\%, $r$ oot p runed; $42 \%, \mathrm{n}$ ot root $\mathrm{p}$ runed; $P<0.05) \mathrm{t}$ hat $\mathrm{g}$ rew t o the $\mathrm{p}$ eriphery o $\mathrm{fb}$ oth $9.5 \mathrm{~L}$ co ntainers ( $\mathrm{d}$ ata $\mathrm{n}$ ot $\mathrm{s}$ hown).

Percentage of total-tree root cross-sectional area (CSA) in $\mathrm{t}$ he top $2 \mathrm{~cm} \mathrm{~m}$ easured at the periphery of the $3.8 \mathrm{~L} \mathrm{r}$ oot ball was larger for trees grown in PC1 than in SC1 containers for both retention times from both propagation co ntainers (Table 5). Both the number of horizontal roots (those growing 0 t o 45 deg rees from the surface) and CSA of the five largest horizontal roots were approximately two to three times larger for trees in PC1 than SM1 containers. $\alpha$ e ratio of diameter in the five largest horizontal to diameter in the five largest descending roots (those growing 45 to 90 degrees from surface) was eight and three times greater for PC1 than SC1 for 6 a nd $13 \mathrm{~m}$ onths retention time, $\mathrm{r}$ espectively. $\mathrm{G}$ rowing $\mathrm{t}$ rees in $\mathrm{SC} 1 \mathrm{co}$ ntainers $\mathrm{r}$ esulted in a $\mathrm{g}$ reater a $\mathrm{rc} \mathrm{w}$ ithout roots $(>1 \mathrm{~mm}$ di ameter) than growing in PC1 a fter $6 \mathrm{~m}$ onths in $3.8 \mathrm{~L}$ co $\mathrm{n}$ tainers; there was no difference at 13 months. Root depth $f$ or $t$ rees $f$ rom $b$ oth $p$ ropagation co ntainer types wa s n ot a ffected b y $3.8 \mathrm{~L}$ co ntainer $\mathrm{t}$ ype 6 months a fter s hifting b ut wa s sig nificantly g reater in SC1 than PC1 13 months after shifting (Table 5).

Impact $f$ rom g rowing $m$ ahogany $t$ rees in $3.8 \mathrm{~L}$ and $9.5 \mathrm{~L}$ co ntainers of $\mathrm{t}$ wo $\mathrm{t}$ ypes wa s co nsistent (i.e., there was no in teraction) across propagation container type, retention time in p ropagation container, and root pruning for 11 measured attributes (Table 6; Figur e 2). Trees harvested from SC3 co ntainers had slightly larger trunk diameter and totaltree height $(P<0.05) \mathrm{t}$ han $\mathrm{t}$ rees from PC3. R oots on trees from SC3 $h$ ad hig her values of a ttributes associated with lower quality, including \% trunk circled with roots, $3.8 \mathrm{~L}$ container imprint rating, root cull (graded according to Florida Grades and Standards, A nonymous 1998), a nd total deflected root length. Trees in PC3 containers had about six times the number of straight roots $(69 \%$ vs. $11 \%$ of roots $>3 \mathrm{~mm}$ diameter) as those in SC3 containers. Trees in PC3 had $44 \%$ of root system CSA de eper than 8 $\mathrm{cm}$ at the periphery of the $9.5 \mathrm{~L}$ co ntainer, whereas $83 \%$ was positioned there on trees in SC3 co ntainers. Ratio CSA of five largest horizontal to five largest descending roots was $49 \mathrm{t}$ imes greater on trees from PC3 than SC3 containers (Table 6; Figure 2).

Impact on growing trees in $3.8 \mathrm{~L}$ a nd $9.5 \mathrm{~L}$ co $\mathrm{n}$ tainers depended on the propagation container type for four root attributes (Table 7). G rowing trees in EP a nd then shifting to PC1 a nd PC3 $r$ esulted in the le ast $\% \mathrm{t}$ runk cir cled a nd \% $\mathrm{t}$ rees $\mathrm{w}$ ith $\mathrm{r}$ oots that touched or cr ossed $w$ ithin the dim ensions of the $\mathrm{p}$ ropagation co ntainer. $\mathrm{F}$ or $\mathrm{b}$ oth $\mathrm{p}$ ropagation

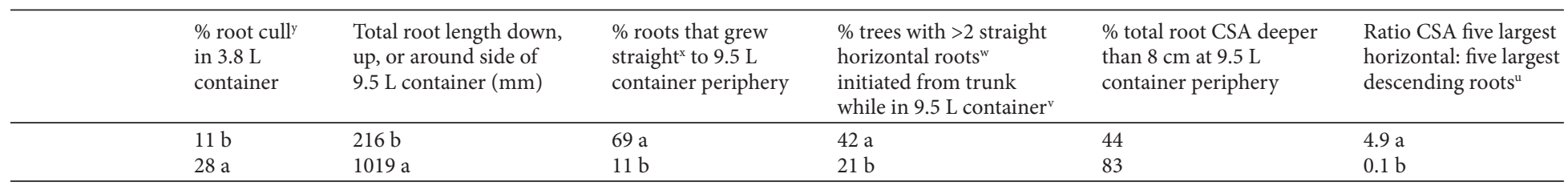


Table 7. Interaction of propagation container type with $3.8 \mathrm{~L}$ and $9.5 \mathrm{~L}$ container type on mahogany roots (>3 mm diameter) harvested in $9.5 \mathrm{~L}$ containers April and October 2011.

\begin{tabular}{lllll}
\hline $\begin{array}{l}\text { Propagation container } \\
\text { (liner) type }\end{array}$ & $\begin{array}{l}3.8 \mathrm{~L} \text { and 9.5 } \mathrm{L} \\
\text { container type }\end{array}$ & $\begin{array}{l}\text { \% trunk circled at } \\
\text { liner position }\end{array}$ & $\begin{array}{l}\text { \% trees with roots } \\
\text { within liner dimension } \\
\text { that cross or touch }\end{array}$ & $\begin{array}{l}\text { No. of horizontal } \\
\text { straight roots } \\
\text { from flare }\end{array}$ \\
\hline SM & PC3 & $40 \mathrm{a}^{\mathrm{x}}$ & $57 \mathrm{~b}$ & $\begin{array}{l}\text { \% roots that grew } \\
\text { to 9.5 container } \\
\text { periphery }\end{array}$ \\
& SC3 & $34 \mathrm{a}$ & $81 \mathrm{a}$ & $63 \mathrm{~b}$ \\
EP & PC3 & $3 \mathrm{~b}$ & $5 \mathrm{c}$ a & $8.7 \mathrm{a}$ \\
& SC3 & $22 \mathrm{a}$ & $71 \mathrm{ab}$ & $76 \mathrm{c}$ \\
$5 \mathrm{~d}$
\end{tabular}

${ }^{\mathrm{z}}$ Straight roots were those $>3 \mathrm{~mm}$ diameter measured just inside the $9.5 \mathrm{~L}$ container sides that grew from trunk at $<45$ degree angle to surface without making a turn of $>60$ degrees relative to parent root azimuth at trunk.

${ }^{y}$ Roots that remained larger than $3 \mathrm{~mm}$ diameter while growing to the $9.5 \mathrm{~L}$ container side, not including those that touched the bottom first.

${ }^{x}$ Means in a column with a different letter are statistically different at $P<0.05 ; \mathrm{n}=21$ averaged across these three treatment combinations: 5 or 12 months in propagation container without root pruning when shifting to $3.8 \mathrm{~L}$ container, and 12 months retention with root pruning due to insignificant interaction. Results were similar for trees harvested in $3.8 \mathrm{~L}$ containers (data not shown).

Table 8. Effect of retention time in 3.8 L container on mahogany in 9.5 L containers September 2010 and April 2011.

\begin{tabular}{|c|c|c|c|c|}
\hline $\begin{array}{l}\text { Retention time in } \\
3.8 \text { L containers } \\
\text { (months) }\end{array}$ & $\begin{array}{l}\% \text { trunk circled in top } \\
\text { half of } 3.8 \mathrm{~L} \text { container } \\
\text { position }\end{array}$ & $\begin{array}{l}\% \text { cull at } 3.8 \mathrm{~L} \text { container } \\
\text { position }\end{array}$ & $\begin{array}{l}\text { Total length of roots growing } \\
\text { down, up, or around side } \\
\text { of } 9.5 \mathrm{~L} \text { container }(\mathrm{mm})\end{array}$ & $\begin{array}{l}\% \text { CSA of horizontal roots } \\
\text { deeper than } 8 \mathrm{~cm} \text { at } 9.5 \mathrm{~L} \\
\text { container periphery }\end{array}$ \\
\hline 6 & $6 b^{y}$ & $3 \mathrm{~b}$ & $474 \mathrm{~b}$ & $66 \mathrm{a}$ \\
\hline 13 & $25 \mathrm{a}$ & $31 \mathrm{a}$ & $798 \mathrm{a}$ & $61 \mathrm{~b}$ \\
\hline
\end{tabular}

container types, growing trees in PC3 resulted in a threefold or more increase in number of horizontal straight roots (those $>3 \mathrm{~mm}$ diameter) and \% roots that grew to the $9.5 \mathrm{~L}$ container periphery compared to trees in SC3. à e longer retention time in both 3.8 $\mathrm{L}$ containers was associated with greater root circling and deflection, reduced quality, and slightly greater depth o f h orizontally o riented $\mathrm{r}$ oots (T able 8).

\section{DISCUSSION}

Retaining trees in co ntainers for different time periods, a nd r oot p runing or $n$ ot $w$ hen $s$ hifting the liner, $\mathrm{r}$ esulted in $\mathrm{f}$ ew $\mathrm{m}$ eaningful differences in trunk di ameter and tree height at the en $d$ of the study when trees were in $9.5 \mathrm{~L}$ containers; container type had only a s light effect. Trees in SC co ntainers were larger than those in PC probably d ue to drier conditions (n ot measured) in PC co ntainers. ái $s$ wa s a ttributable t o the $\mathrm{p}$ orous $\mathrm{n}$ ature of the container sides a nd bottom; fabric containers with porous sides $h$ ave b een shown $t o$ in crease e vaporation from $t$ he co ntainer root $b$ all (A rnold a nd McDonald 2006). Irrigation management could be ad justed t o $\mathrm{m}$ aintain hig her m oisture co ntent.

Finished lin ers in EP $h$ ad a ttributes a ssociated with hig $\mathrm{h}$ q uality $\mathrm{r}$ oot sys tems best des cribed as an a bundance of $\mathrm{h}$ orizontal s traight $\mathrm{r}$ oots g rowing from an aborted tap root (B alisky et a 1. 1995;
Svensen et al. 1995); r oots in the o ther two liners were deflected downward and around the container (Table 1; Figure 1). EP propagation containers that were inserted into smooth-sided liner cells (EPS) produced root systems similar to those in SM (Table 1), which indicated that the paper comprising the sides of EP s hould b e exp osed to a ir, not placed against a solid plastic wall. When finished in 3.8 L containers, root systems from EPS containers had a m ore prominent liner imprint (Harris et a l. 1971) than those propagated in S M (Table 2). $\dot{\alpha}$ e slim air gap b etween the plastic sides a nd the EP paper created an ideal environment for root growth and caused this im print formed by roots circling, ascending, and des cending $m$ ostly o utside of the paper. Mahogany s hould $n$ ot b e g rown $u$ sing the EPS sys tem b ecause it en couraged a s evere $r$ oot imprint at the position of the liner. In contrast, trees propagated in EP a nd finished in ei ther $3.8 \mathrm{~L}$ co ntainer type had almost no measurable root circling or im print at $t$ he $\mathrm{p}$ osition of $\mathrm{t}$ he lin er (Table 2).

Mahogany root def ects at $t$ he lin er p osition on trees in $3.8 \mathrm{~L}$ co ntainers in creased $w$ ith retention time in S M propagation containers but not for EP containers (Table 3) as in other studies (Salonius et al. 2000; Gilman et al. 2012). However, root pruning SM liners retained 12 months when shifting to $3.8 \mathrm{~L}$ containers dramatically reduced defects at the liner 
position (Table 4) without impacting trunk or height growth ( $\mathrm{d}$ ata not $s$ hown). ài $s$ en hancement of quality did $n$ ot occur for trees propagated in EP b ecause there were far fewer defects to r emove (Table 1). M echanical root pruning was also a reliable method of managing roots of other tree species when $s$ hifting lin ers $t o$ larger co ntainers ( $G$ ilman et a 1 . 2012), o r w hen p lanting in to field s oil ( $\mathrm{K}$ rasowski a nd $\mathrm{O}$ wens 2000). ói s eliminates the imprint imposed o $\mathrm{n} t$ he $\mathrm{r}$ oot sys tem b y the co ntainer, $w$ hich $r$ educes the li kelihood of $s$ tem $g$ irdling roots a nd $\mathrm{c}$ an en hance a nchorage (G ilman a nd $W$ iese 2012).

Propagation co ntainert ype failed to influence consistently any measured attribute across both 9.5 L container types; i.e., the effect of propagation $t$ ype dep ended $\mathrm{o} n$ which 1 arger co ntainer wa s u sed when data was a veraged across 5 and $12 \mathrm{~m}$ onths retention time in propagation co ntainers a nd $\mathrm{r}$ oot pruning (T able 7). I n co ntrast, the effect of larger container type (either PC o r SC) wa s consistent for nin e $r$ oot a ttributes of $t$ rees propagated from ei ther p ropagation type (Table 6). ải $\mathrm{s}$ analysis could fa lsely le ad u s to conclude that root quality dep ended more on the $3.8 \mathrm{~L}$ a nd $9.5 \mathrm{~L}$ co ntainer type, and less on the propagation container $t$ ype. $\mathrm{H}$ owever, $\mathrm{w}$ hen data wa $s$ a veraged acr oss $r$ etention $\mathrm{t}$ ime in $3.8 \mathrm{~L}$ co ntainers on trees $r$ etained $f$ or $5 \mathrm{~m}$ onths in propagation containers, propagation $t$ ype had a sig nificant effect on root morphology in the 9.5

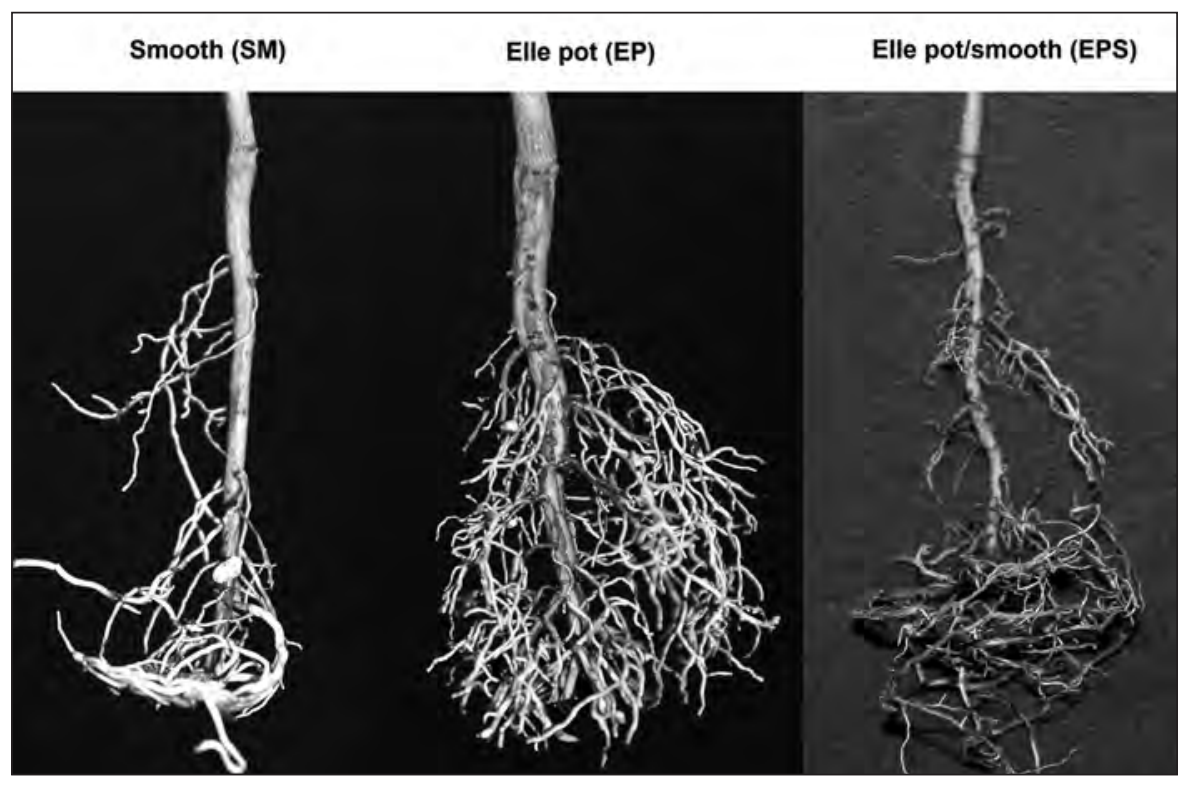

Figure 1. Root systems after 5 months in three propagation containers. The largediameter lateral woody roots emerging from the tap root in EP are lacking on the other two.

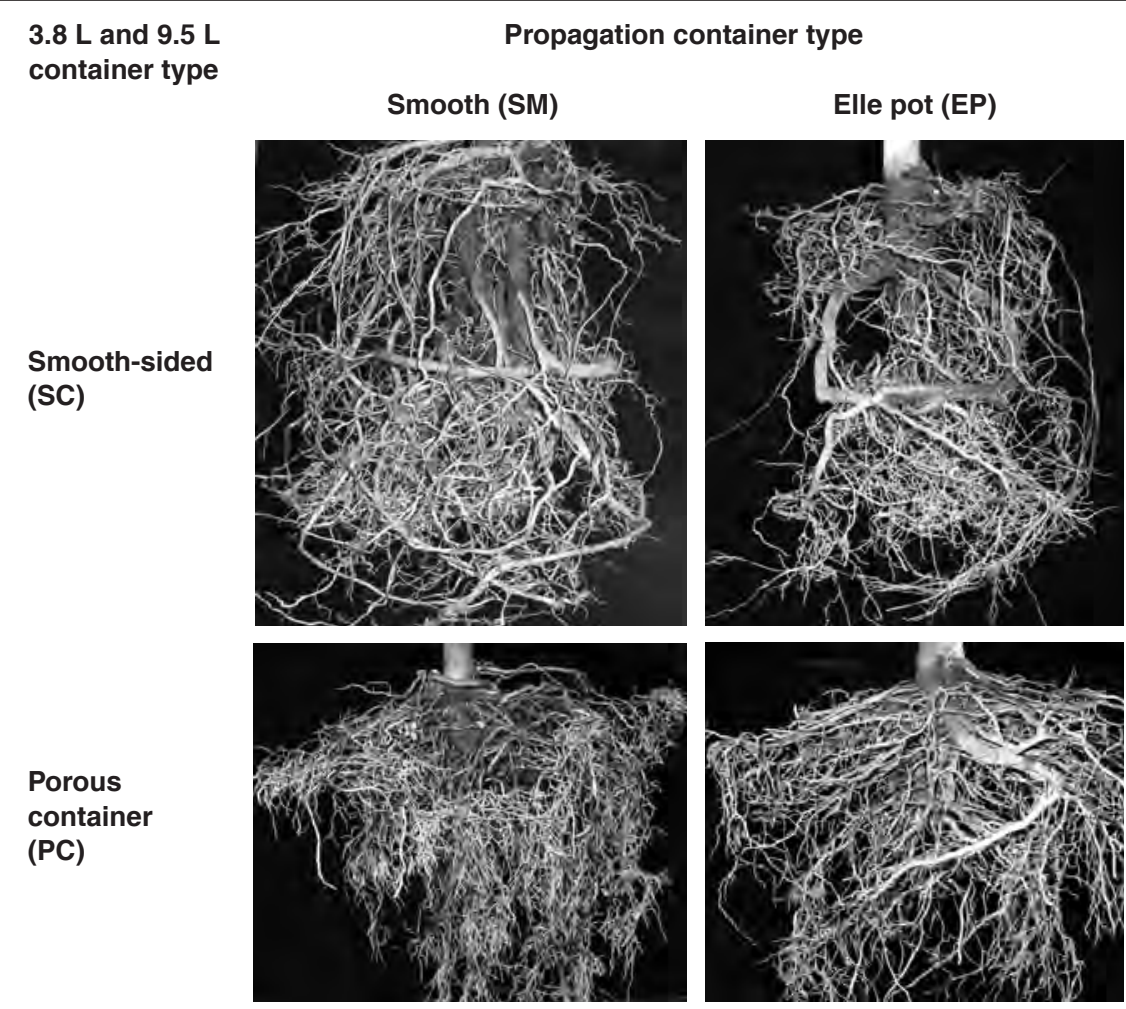

Figure 2. Root systems in $9.5 \mathrm{~L}$ containers for six months, grown in four combinations of propagation container and larger $(3.8 \mathrm{~L}$ and $9.5 \mathrm{~L})$ container.

butes for $\mathrm{t}$ rees $\mathrm{g}$ rown in EP $\mathrm{p}$ ropagation co ntainers ( $8 \%, 3 \%$, and 1.7 , respectively, data not shown). ải $s$ analysis shows that both propagation container and the larger container im pacted $r$ oot q uality. 
$\dot{\alpha}$ e deeper and deflected nature of the root system in finished SM lin ers (Table 1) li kely explains the abundance of root defects at the lin er position in both $9.5 \mathrm{~L}$ container types (Table 7). Trees did not grow out of that condition created in the propagation liner in either larger container type. á e lack of root deflection in EP propagation containers (Table 1) was responsible for the small imprint at that position and far g reater number of r oots reaching the side wa lls (p eriphery) of the PC $9.5 \mathrm{~L}$ co ntainer (Table 7; Figure 2). Root tips in EP lin ers remained in the horizontal position near the liner periphery without deflection, which positioned them for growing horizontally in to the PC co ntainer. However, in SC 9.5 L co ntainers, r oot defects on t rees propagated in EP mimic ked those of $t$ rees propagated in S M liners, suggesting that the b enefits of growing a high-quality root system in the liner (i.e., in EP) di sappeared when shifting in to a 1 arger SC container. ả $\mathrm{s}$ was attributable to the largest roots from $b$ oth $p$ ropagation co ntainer $t$ ypes $g$ rowing downward from the bottom of the liner to the bottom of the 3.8 L and 9.5 L SC containers (Table 4). Once at the bottom, roots deflected and continued to $g$ row along the bottom forming an imprint that remained with the tree in the $9.5 \mathrm{~L}$ container (Table 6; Figure 2) a s o thers have found for smaller containers (S elby and Seaby 1982). A ggressive growth at the bottom of the $3.8 \mathrm{~L} \mathrm{SC}$ containers appeared to inhibit initiation or growth of horizontal roots closer to the substrate surface, and resulted in a vertically oriented and circling root system on finished 9.5 L SC t rees (Figure 2). Deflection of structural roots downward in the container forced them to $g$ row $\mathrm{p}$ arallel a nd cr oss o ne a nother dir ectly under the trunk (Table 7) causing constrictions and inclusions that can restrict $\mathrm{p}$ assage of substances through vascular tissue (Lindström and Rune 1999).

In contrast to SC containers, growing trees in PC produced a root system with a more horizontal than vertical orientation (Table 6; Figure 2). ải s has not been reported before for containers of this large size. Vertical root growth was discouraged by the elevated and hig hly p orous b ottom that stopped elongation of roots that penetrated it. Vertical roots died back (brown root tips growing through the bottom were visible) once exposed to the dry air beneath the elevated $b$ ottom which effectively r oot p runed them. Air pruning at the bottom appeared similar to that of at least one other container that prunes with air (Gilman et a 1. 2010). I nhibition of des cending vertical roots induced formation of new roots or growth on existing roots close to the soil surface, and promoted growth in $\mathrm{h}$ orizontal-oriented $\mathrm{r}$ oots di stributed throughout $t$ he $\mathrm{r}$ oot $\mathrm{b}$ all $\mathrm{p}$ rofile. $\dot{\alpha}$ e t remendous (49-fold, Table 6) increase in horizontal growth in 9.5 L PC wa s caused by a co mbination of 1) co ntinued growth on existing non-deflected horizontal roots in the 3.8 L PC containers (Table 5), and 2) initiation of new horizontal roots at the flare in the $9.5 \mathrm{~L}$ container (Table 6). $\mathrm{N}$ either of these phenomena occurred in SC containers. Mahogany trees with horizontal-oriented lateral roots close to the top surface of the root ball develop a different root system in the landscape than those with vertical and circling roots, le ading to $b$ etter a nchorage ( $\mathrm{G}$ ilman a nd $\mathrm{H}$ archick 2014).

\section{CONCLUSION}

Mahogany root systems in a container can beg rown w ith a ttributes a ssociated $w$ ith well-anchored 1 andscape $\mathrm{t}$ rees ( $\mathrm{i}$.e., $\mathrm{w}$ ith straight $r$ oots, $s$ ome c lose $t$ ot hes urface).

Acknowledgments. $\mathfrak{\alpha}$ anks to the Horticulture Research Institute, GreatSouthernTreeConference.org (w hich in cluded funding from the co ntainer $m$ anufacturers of the tested a nd o ther co ntainers), and Quintessence Nursery for partial funding.

\section{LITERATURE CITED}

Anonymous. 1998. Flo rida $\mathrm{G}$ rades a nd $\mathrm{S}$ tandards $\mathrm{f}$ or $\mathrm{N}$ ursery Plants. Florida Department of Agriculture and Consumer Services, Gainesville, Florida, U.S.

Arnold, M.A., and G.V. McDonald. 2006. Shrub rose responses to production in $\mathrm{S}$ mart $\mathrm{P}$ ots a nd co nventional co ntainers u sing two contrasting substrates. Subtropical Plant Science Journal of the Rio Grande Valley Horticulture Society 58:1-4.

Balisky, A.C., P. Salonius, C. Walli, and D. Brinkman. 1995. Seedling roots and forest floor: Misplaced and neglected aspects of British Columbia's reforestation effort. Forestry Chronicle 71:59-65.

Burdett, A.N. 1978. C ontrol of root morphogenesis for improved stability in co ntainer-grown lo dgepole pine. Canadian Journal of Forest Research 8:483-486.

Coutts, M.P., C. W alker, a nd A.C. B urnand. 1990. Effects of establishment method on root form of lodgepole pine and Sitka spruce and on the p roduction of ad ventitious r oots. F orestry 63:143-159.

Gilman, E.F., and C. H archick. 2014. C ontainer design influences Swietenia mahagoni root attributes and anchorage after landscape planting. Arboriculture \& Urban Forestry 40:27-35.

Gilman, E.F., a nd C. W iese. 2012. R oot p runing at planting a nd planting depth in the nursery impact root system morphology and anchorage. Arboriculture \& Urban Forestry 38:232-239. 
Gilman, E.F., and M. Orfanedes. 2012. Root pruning and planting depth impact root morphology in containers. Journal of Envi ronmental Horticulture 30:173-181.

Gilman, E.F., I.A. Leone, and F.B. Flower. 1987. Effect of soil compaction a nd o xygen co ntent o $\mathrm{n} v$ ertical a nd h orizontal $\mathrm{r}$ oot distribution. Journal of Environmental Horticulture 5:33-36.

Gilman, E.F., M. P az, and C. H archick. 2010. Effect of co ntainer type on root form and growth of red maple. Journal of Environmental Horticulture 28:1-7.

Gilman, E.F., M. Paz., D. Meador, and P. Fisher. 2012. Propagation container type, time in co ntainer, and root pruning affect root development of young Acer rubrum. Journal of Environmental Horticulture 30:150-160.

Harris, R.W., W.B. Davis, N.W. Stice, and D. Long. 1971. Influence of transplanting time in nursery production. Journal American Society Horticulture Science 96:109-110.

Hewitt, A., and G. Watson. 2009. Bare root liner production can alter $t$ ree $r$ oot a rchitecture. A rboriculture \& $\mathrm{U}$ rban F orestry 27:99-104.

Krasowski, M.J. 2003. Root system modifications by nursery culture reflect on post-planting growth and development of coniferous seedlings. Forest Chronicle 79:882-891.

Krasowski, M.J., and J.N. Owens. 2000. Morphological and physical attributes of root systems and seedlings growth in three different Picea glauca reforestation stock. Canadian Journal of Forest Research 30:1669-1681.

Lindström, A., and G. Rune. 1999. Root deformation in plantations of container-grown Scots pine trees: Effects on root growth, tree stability and stem straightness. Plant and Soil 217:29-37.

Marshall, M.D., and E.F. Gilman. 1998. Effects of nursery container type on root growth and landscape establishment of Acer $\mathrm{ru}$ brum L. Journal of Environmental Horticulture 16:55-59.

Orlander, G. 1982. à e air-pruned seedling - A solution to the rootdeformation problem? pp. 91-94. In: H. Hulten, (Ed.). Root deformation of forest tree seedlings - proceedings of a Nordic symposium, Ga rpenberg, 1981. S wedish University at A gricultural Sciences, Department of Forest Yield Research. Report No. 11.

Ortega, U ., J . M ajada, A. M ena-Petite, J . Sa nchez-Zabala, N. Rodriguez-Itturrizar, K. Txarterina, J. Azpitarte, and M. Duñabeitia. 2006. Field performance of Pinus radiata D. Don produced in $n$ ursery with different types of co ntainers. New Forests 31:97-112.

Salonius, P., K. B eaton, and B. Roze. 2000. Effects of cell size a nd spacing o $\mathrm{n}$ r oot den sity a nd field p erformance of co ntainerreared black spruce. Information Report M-X-208E, C anadian Forest $\mathrm{S}$ ervice, $\mathrm{A}$ tlantic $\mathrm{F}$ orestry $\mathrm{C}$ entre, $\mathrm{F}$ rederickton, $\mathrm{N}$ ew Brunswick, Canada.

Selby, C., and D.A. Seaby. 1982. à e effect of auxins on Pinus contorta seedling root development. Forestry 55:125-135.

Struve, D.K. 1993. Effect of copper-treated containers on transplant survival and regrowth of four tree species. Journal of Environmental Horticulture 11:196-199.

Svensen, S.E., D .L. Johnston, and B.L. C oy. 1995. S hoot and root responses of eight subtropical species grown in apric hydroxidetreated containers. HortScience 30:249-251.

Watson, G.W., and G. Kupkowski. 1991. Effects of a de ep layer of mulch on the soil environment and tree root growth. Journal of Arboriculture 17:242-245.
Weicherding, P.J., C.P. Giblin, J.H. Gillman, D.L. Hanson, and G. Johnson. 2007. Mechanical root-disruption practices and their effect o n cir cling r oots of p ot-bound Tilia $c$ ordata $\mathrm{M}$ ill. a nd Salix alba L. 'Niobe'. Arboriculture \& Urban Forestry 33:43-47.

Edward F. Gilman (corresponding author)

Environmental Horticulture Department

University of Florida

Gainesville, Florida, U.S.

egilman@uả.edu

Maria Paz

Environmental Horticulture Department

University of Florida

Gainesville, Florida, U.S.

Résumé. $\mathrm{D}$ ans des $\mathrm{p}$ ots de $\mathrm{p}$ épinière, un $\mathrm{m}$ auvais a ncrage et une mise en place retardée ont été associés avec l'observation de racines tournantes, ascendantes et descendantes, ainsi qu'entortillées. L'objectif principal de cette étude était de trouver des méthodes de production à partir des graines de Swietenia mahagoni ( L. ) J acq . qui produisent des racin es droites non déformées. Contrairement à des p ots de propagation à p arois lisses (géo membranes), les ra cines qui poussent dans des pots de papier fin sont restées droites et très peu déformées. Lélagage des racines provenant de pots à géo membrane de 12 mois au moment de leur déplacement dans un pot de 3,8 L a considérablement réduit l'empreinte des déformations des racines sur le système racinaire. Une croissance agressive dans le fond des p ots à p arois lisses de 3,8 L et 9,5 L s emble in hiber la croissance horizontale des racines près de la surface du substrat, et aboutit à un sys tème racinaire orienté verticalement. En revanche, pour les arbres qui poussent dans des pots de $3,8 \mathrm{~L}$ et $9,5 \mathrm{~L}$ à parois extrêmement poreuses, un système racinaire plus orienté horizontalement a été observé, semblablement aux arbres bien ancrés dans la nature. Le développement des racin es verticales a ét é freiné en raison du fond surélevé et p oreux du pot, ce qui a obligé celles-ci à pousser de façon plus horizontale et plus haut dans le profil de la motte. Les déformations des racines ont augmenté en concordance avec le temps de rétention dans tous les pots.

Zusammenfassung. $\mathrm{S}$ chlechte $\mathrm{V}$ erankerung un $\mathrm{d} \mathrm{v}$ erzögerte Entwicklung wurden bislang mit der B ildung von Würgewurzeln, auf- o der a bsteigenden s owie geknickten Wurzeln in B aumschulcontainern gebracht. Das Hauptziel dieser Studie lag darin, Methoden der Produktion von Swietenia mahagoni (L.) Jacq. aus Samen mit graden, undeformierten Wurzeln zu finden. Im Gegensatz zu weichen V ermehrungscontainern (S M-liner) wa ren die W urzeln aus Töpfen mit dünnen Papierwänden gerade mit ein $\mathrm{p}$ aar Windungen. Ein W urzelschnitt b ei 12-M onate a lten S M-linern, w enn diese in 3,81 Containern verpflanzt wurden, reduzierte dramatisch die W irkung a uf $\mathrm{d}$ as v erbliebene a bgelenkte W urzelsystem. A ggressives Wachstum am Boden der 3,81 und 9,5 1 weichwandigen Container s chien das Wachstum horizontaler Wurzel, die dic hter an der Oberfläche des Substrates wuchsen zu behindern und resultierte in ein em vertikal orientiertem Wurzelsystem. Im Gegensatz dazu führte die A ufzucht der B äume in 3,8 l un d 9,5 l C ontainern mit außergewöhnlich porösen Wänden zur Bildung von mehr horizontal o rientierten Wurzelsystemen, ä hnlich wie sich Bäume in der freien Landschaft gut verankern. Vertikale Wurzeln wurden am Wachstum durch einen hochgezogenen und porösen Boden gehindert, da die Wurzeln gezwungen werden, weiter oben mehr in die Horizontale des Wurzelballens zu wachsen. Wurzelverdrehungen nahmen zu mit der Verweildauer in allen Containern. 
Resumen. El anclaje pobre y el establecimiento retardado de los árboles se han asociado con raíces enrolladas, ascendentes, descendentes y es tranguladoras que se producen en los co ntenedores de vivero. El objetivo principal de este estudio fue encontrar métodos de producción con raíces rectas no deformadas a partir de semillas de Swietenia mahagoni (L.) Jacq. En contraste con los contenedores de propagación de lados lisos (SM), las raíces cultivadas en macetas fabricadas con papel delgado fueron derechas con pocas deflexiones. La poda de ra íces de $12 \mathrm{~m}$ eses de e dad de co ntenedores SM, al c ambiar a r ecipientes de 3,8 L, r edujo drá sticamente la h uella en el sistema de la raíz dejada por las desviaciones. El crecimiento agresivo en la parte inferior de los contenedores de lados lisos de 3,8 L y 9,5 L p areció inhibir el crecimiento de raíces horizontales más cerca de la superficie del sustrato y dio lugar a un sistema de raíces orientado v erticalmente. En co ntraste, los á rboles que cr ecen en contenedores con paredes excepcionalmente porosas de 3,8 L y 9,5 $\mathrm{L}$, lograron un sistema de raíces orientado horizontalmente, similar a los árboles bien anclados en el paisaje. Las raíces verticales no se desarrollaron debido a un $\mathrm{f}$ ondo elevado y p oroso, obligándolas a crecer más horizontalmente y a mayor altura en el perfil de la bola del cepellón. Las deflexiones de raíz aumentaron con el tiempo de retención en todos los contenedores. 